Міняйло, Наталія. «Мовностилістичні засоби і прийоми підсилення експресії в романі Олександра Солженіцина "У колі першому"». Лінгвостилістичні студії, вип. 12, 2020, с. 139-49.

Miniailo, Natalia. "Linguo-stylistic Devices and Means of Heightening Expressiveness in the Novel "In the First Circle" by Alexander Solzhenitsyn". Linguostylistic Studies, iss. 12, 2020, pp. 139-49.

УДК 811.161.1'38

https://doi.org/10.29038/2413-0923-2020-12-139-149

\title{
МОВНОСТИЛІСТИЧНІ ЗАСОБИ І ПРИЙОМИ ПІДСИЛЕННЯ ЕКСПРЕСІЇ В РОМАНІ ОЛЕКСАНДРА СОЛЖЕНІЦИНА «У КОЛІ ПЕРШОМУ»
}

\author{
Наталія Міняйло \\ Харківський національний педагогічний університет імені Г. С. Сковороди, \\ Харків, Україна
}

У статті проаналізовано експресивно-стилістичні елементи в тексті роману 0. Солженіцина «У колі першому». Виснувано, що розмовна лексика, акцентовані повтори окремих слів, недомовки, метафори, іронія, парадокс, контраст, окличні й питальні конструкції характеризують оповідь загалом і образи персонажів роману зокрема. Семантично експресивність насамперед пов'язана 3 вираженням емоцій окремого персонажа, які передано у його внутрішніх монологах або зовнішніх діалогах.

Ключові слова: діалог, монолог, експресія, метафорична конструкція, контраст, парадокс.

\section{LINGUO-STYLISTIC DEVICES AND MEANS OF HEIGHTENING EXPRESSIVENESS IN THE NOVEL “IN THE FIRST CIRCLE” BY ALEXANDER SOLZHENITSYN Natalia Miniailo \\ H. S. Skovoroda Kharkiv National Pedagogical University, Kharkiv, Ukraine}

The article analyzes the expressive stylistic elements, which add dynamics to narrative description, highlight and emphasize the emotional or aesthetic content in the text of the novel "In the First Circle" by A. Solzhenitsyn. The analysis involves the identification of the main functions of the expressive features in the artistic text and interpretation of them in terms of the functional-stylistic method. The functional-stylistic method is used to study the linguistic means of expressiveness enhancement that characterize the story, in general, and the speech of the characters, in particular. The study has revealed such stylistic techniques and means as the use of phonographical means and dialect vocabulary, repetition, understatement, metaphorical constructions, ironic and paradoxical content, contrast, the unusual syntactic organization of text (exclamation and interrogative constructions, speech devices of impulsivity).

The unexpected transitions from one subject's speech area to another are formally indicated by insertion words, parentheses, and subjective elements as traditional techniques to enhance expression. In the focus of a meticulous study are the examples of irony and paradox that make the reader not only observe the events and objects described but also analyze the mysterious formulas perceived in a different way by each reader. Semantic expressiveness is more related to the expression of the emotions of an individual character, conveyed in his internal monologues or external dialogues.

(C) Міняйло Н., Східноєвропейський національний університет імені Лесі Українки, 2020.

Це стаття відкритого доступу на умовах CC BY-NC 4.0 
The case study of the article argues that stylistic devices and expressive means like the use of colloquial vocabulary, repetitions of words, understatement, metaphors, irony, paradox, contrast, exclamation, and interrogative structures make the whole artistic text more expressive and, particularly, the characters' speech.

Key words: dialogue, monologue, expressiveness, metaphorical construction, contrast, paradox.

Вступ. У межах загального розгляду стилістики роману «У колі першому» предметом аналізу є засоби подання інформації в тексті - форми зображення подій та об'єктів, статичний і динамічний виміри такого зображення (через дієслівні, предметні й означальні послідовності). Важливими $\epsilon$ й експресивно-стилістичні елементи, що додають оповіді динаміки. Однак головна функція експресивних рис- характеристика оповіді загалом і героїв зокрема, коли для посилення, виділення, підкреслення, емоційного чи естетичного наповнення тексту використовують різноманітні стилістичні прийоми й засоби.

Створення експресії в художньому тексті та її форми були об'єктом досліджень у різних лінгвістичних площинах: О. Вольф вивчала емоційні стани та їхню репрезентацію в мові, О. Філатова - інтонаційне наповнення експресивних фрагментів тексту, В.Шульгіна визначала синтаксичні особливості живого мовлення в художньому тексті, К. Штайн - поетику літературного твору, зокрема використовування в ньому стилістичних прийомів і засобів для створення експресії. І оскільки експресивне подання інформації у творі розраховане передусім на реакцію читача, то вивчають і такі відносини - між автором, персонажем і читачем (починаючи від М. Бахтіна, В. Виноградова, які приділяли увагу авторові та його ролі в оповідній сфері художнього твору, до А. Гулака, І. Ковтунової, О. Падучевої, О. Шкурської, які в розгляді видів оповіді, зокрема вільного непрямого дискурсу, відзначали й експресивні елементи. Ми також, вивчаючи мову роману «У колі першому», відзначали роль засобів підсилення експресії в мовностильовій площині (характеристика ідіостилю О.Солженіцина) (Гулак, и Меняйло) та мовно-психологічній (характеристика образів персонажів) (Меняйло).

У присвячених мові О. Солженіцина наукових дослідженнях дотепер докладно не вивчено засоби створення експресії, зокрема й у романі «У колі першому», де вони характеризують як саму оповідь загалом, так і психологію образів дійових осіб твору.

Мета пропонованої статті - дослідити засоби і прийоми створення експресії в означеному романі.

Відповідно до мети визначено завдання: розглянути в тексті приклади із застосуванням таких мовностилістичних засобів і прийомів, як уживання просторічної та діалектної лексики, повторів (зокрема емфази), недомовок, метафоричних конструкцій, іронічних i парадоксальних контентів, контрасту, на рівні синтаксису - окличних і питальних конструкцій, мовленнєвих ознак імпульсивності. 
Матеріал і методи дослідження. За матеріал дослідження правив текст роману О.Солженіцина «У колі першому». Для його аналізу використано антропоцентричний підхід в аспекті співвіднесення автороповідач - персонаж-оповідач - імпліцитний читач. Функційностилістичний метод застосовано для дослідження використаних автором мовних засобів підсилення експресії, а структурно-стилістичний - для визначення функцій, значення або призначення мовних елементів, на яких акцентовано увагу читача.

Результати дослідження та дискусія. Дослідниця мови Олександра Солженіцина Т. Клеофастова виявила особливу лексику, синтаксис, інтонацію, що $€$ продовженням традицій Ф.Достоєвського, М. Гоголя, О. Пушкіна, Л. Толстого, але 3 використовуванням «народнопоетичної скарбниці живої розмовної мови російського народу», лексичного «розширення», усіх «можливостей російської мови в багатоплановому, глибинному, структурно-функціональному аспектах - i на рівні універсальних національних концептів, i на семантичному, морфологічному, стилістичних рівнях». <..> Не тільки прислів'я й приказки, а й солженіцинський епітет, метафора, порівняння «тісно пов'язані з народнопоетичною традицією» (Клеофастова 11-12).

Ці елементи в певних умовах і поєднаннях підвищують експресивність як окремої фрази, так і загалом тексту. Наприклад, у межах фрагменту з невласне прямим мовленням (далі - НПМ) уже зовнішня форма виділення фраз (кожна - з нового рядка) створює експресію:

Так мало времени обдумать, $и$ совершенно не $c$ кем посоветоваться!

Неужели есть средства дознаться, кто звонил из автомата? Если говорить только по-русски? Если не задерживаться, быстро уйти? Неужели узнают по телефонному сдавленному голосу? Не может быть такой техники.

Через три-четыре дня он полетит туда сам. Логичнее - подождать. Разумнее - подождать.

Но будет поздно.

O, чёрт - ознобом повело его плечи, непривычные к тяжестям. Уж лучше б он не узнал. Не знал. Не узнал... (Солженицин 8).

у цьому фрагменті послідовність однорідних виділених дієслів у формі інфінітива створює своєрідну загальну імперативну самоорієнтацію героя на дію (телефонне повідомлення). При цьому видова форма не диференціює ці імперативні висловлювання у смисловому вимірі. Сюди слід додати й предикативну сполуку не может быть, яка надає героєві впевненості у виборі (також з аналогійною функцією - модальна частка неужели та підрядний сполучник если). Експресію роздумів створює комплекс питальних речень, що відтворюють імпульсивність думок суб'єкта. До того ж це не лише короткі односкладні чи двоскладні речення, це й складнопідрядне, де з'ясувальну частину також сприймаємо як окреме 
питання (формальний показник - питальний займенник хто). Як окличне оформлене лише перше речення мікротексту, однак окличну інтонацію відчуваємо ще в кількох реченнях. Наприклад, стверджувальні фрази «Не может быть такой техники» або «Уж лучше б он не узнал» могли б бути, за бажання автора, відповідно оформлені.

Традиційними прийомами підвищення експресії $\epsilon$ повтор, недомовка й уживання розмовної (просторічної, діалектної тощо) лексики. Так, в аналізованому уривкові із цією метою повторено інфінітив подождать і сполуку не узнал / не знал, обірвано думку (не узнал...) та вжито модальний вигук «о, чёрт» (теж без оформлення окличної інтонації).

У сфері авторського мовлення В. Виноградов також додає до засобів підвищення експресії неочікувані переходи з однієї суб’єктної сфери мовлення в іншу, формально позначені (просигналізовані) вставними словами, реченнями в дужках, елементами суб'єктивації (227). Наприклад, у досліджуваному тексті:

Иннокентий шёл очень прямой и совсем уже не поспешный. На него вскинула глаза встречная девушка.

\section{И ещё одна. Очень милая. Пожелай мне уцелеть.}

Как широк мир, и сколько в нём возможностей! - а у тебя ничего не осталось, только вот это ущелье (Солженицин 9).

Цей фрагмент тексту містить кілька переходів з однієї суб'єктної сфери в іншу зі зміною позиції автора. Перший абзац - авторська оповідь. Показник - дієслово недоконаного виду (на позначення тривалості цієї дії) та дієслово доконаного виду (миттєва дія). У другому абзаці роль наратора переходить до героя - з моменту звернення уваги Інокентія на дівчат - до оцінювання їх i звернення подумки за підтримкою («Пожелай мне уцелеть»). Головним показником НПМ тут $\epsilon$ дієслово волюнтивної семантики пожелай, що виявляє суб'єктну сферу героя. Третій абзац, на нашу думку, - авторське втручання у формі коментаря всеобізнаної людини, спрямованого через особовий займенник до всіх молодих людей, у кого попереду широкий світ і багато можливостей, та конкретно до Інокентія, який свідомо вибрав шлях у прірву.

Ми вважаємо, що до списку експресивних елементів слід додати іронію і парадокс / антитезу, які примушують читача не лише спостерігати за зображуваними подіями та об'єктами, але й аналізувати певні загадкові формули, відповідь на які може бути різною в кожного реципієнта.

Іронія, за словником, має дві дефініції: «прихована насмішка, глузування» та «стилістичний засіб, коли слову або зворотові надається протилежного значення з метою глузування» (Великий 506). Ураховуючи обидва визначення, порівняймо: "Даже те, кто работают в одной из таких комнат, знают о событиях в соседней меньше, чем о рыночных новостях острова Мадагаскара» та «Но по трагическому противоречию между идеальным совершенством государственных устройств и жалким несовершенством человека - инструкция в этот раз была 
нарушена» (Солженицин 11). В обох фрагментах автор глузує з державних службовців. Ця насмішка неприхована, оскільки в першому випадку алегорично оцінено знання працівників про виконувану ними спільну роботу (у формі жартівливого порівняння з далеким Мадагаскаром), а в другому вже висміяно державну систему (виділено об'єкти глузування також із відтінком порівняння та подвійною антитезою- «идеальное совершенство» / жалкое несовершенство, а також що «инструкция в этот раз была нарушена» - і тільки цього разу, бо «по трагическому противоречию»).

Іронію можна спостерігати навіть в описах, зокрема інтер'єру (ніби від усеобізнаного автора), коли наратор зображує орієнтовні ознаки, властиві будь-якій державній установі. Наприклад:

Есть такие учреждения, где натыкаешься на темновато-багровый фонарик у двери: “Служебный». Или, поновей, важную зеркальную табличку: «Вход посторонним категорически воспрещён». $A$ то и грозный вахтёр сидит за столиком, проверяет пропуска. И за недоступной дверью рисуется, как всё запретное, невесть что.

А там - такой же простой коридор, может почище. Средней струёй простелена дорожка красного казённого рядна. В меру натёрт паркет. $B$ меру часто расставлены плевательнищы.

Только безлюдно. Не ходят из двери в дверь.

Двери же - все под чёрной кожей, под вздувшейся от набивки чёрной кожей с белыми заклёпками и зеркальными же оваликами номеров (Солженицин 11).

У цьому фрагменті всеобізнаний автор висміює гіперболізовану секретність радянських установ - через зіставлення виділених словосполучень із традиційними словами зі семантикою важливості та емотивних розмовних форм (натыкаешься, рисуется запретное, невесть что, овалики номеров). Попри іронічну забарвленість це власне опис інтер'єру 3 атрибутами тогочасної обстановки (дорожка красного казённого рядна, паркет, плевательницы, двери под чёрной кожей с белыми заклёпками и зеркальными оваликами номеров). Зрештою секретність виявляється не в атрибутах - об'єктах іронії, а в абзаці «Только безлюдно. Не ходят из двери в дверь».

За словниковими дефініціями термін парадокс визначено як «думка, судження, що різко розходиться зі звичайним, загальноприйнятим i суперечить тверезому глуздові», «нелогічний збіг обставин» (Великий 884). До цього предметного кола можна віднести й антитезові ознаки. Однак слід зауважити, що загалом у романі такі фрагменти можуть визначати (читати) різні реципієнти по-різному, а тому ми висловлюємо власні рефлексії парадоксальних ситуацій і висловлювань. Наприклад:

- Это вот так, бывало, в тридцать девятом - в сороковом Бориса Сергеевича Стечкина с шарашки вызовет Берия, - уж он с пустыми руками 
не вернётся: или начальника тюрьмы переменят, или прогулки увеличат... <...> Хорош человек был Борис Сергеевич, царство ему небесное...

- Умер?

- Нет, освободился... Лауреатом стал (Солженицин 66).

Загальноприйнятим судженням у цьому разі було б схвалення й пишання досягненнями відомого конструктора зброї. Проте порівняння зі смертю «різко розходиться» 3 тим загальноприйнятим, і таке ставлення колишніх колег і співкамерників пояснюється їхнім негативним сприйняттям подальшої співпраці Стечкіна із владою. Це сприйняття маніфестує фраза «хорои человек был Борис Сергеевич», де насамперед акцентовано на виділеному означальному словосполученні, а тоді вже - на минулому часі (был). Відзначаємо також опозиційну пару синонімних позначень смерті: царство ему небесное - умер, де опозиційність виявляється в архаїчності першого (тому комунікант перепитує, використовуючи загальноприйняту лексему).

Порівняймо ще:

<...> от долгого неупражнения ум стал бесполезен министру: вся его карьера складывалась так, что от думанья он проигрывал, а от служебного рвения выцгрывал. И Абакумов старался меньще напрягать голову (Солженицин 78).

Виділені словосполучення позначають парадокс: загальноприйняте уявлення, яке походить від природи людини як Homo sapiens, що саме розум виокремлює їі серед інших тварин, тут заперечено. До того ж парадокс збільшується через нагадування високого соціального статусу Абакумова (министр), а також через указівку на прямо протилежний ефект думання - програш у справах. Відзначаємо також елементи іронії автора - антагоністичну опозицію «думанье - служебное рвение» (тобто їі елементи взаємозаперечні) та відомий афоризм радянських часів «меньше напрягать голову», що також становить антитезу зі статусом міністра.

Тягар «думання» характеризує й особу найвищого статусу - Сталіна, у міркуванні якого воно сполучається із часовою / віковою площиною: скільки ще заплановано жити (20 років), і відповідно стільки буде гнітити думання. Порівняймо: «Думать - был его долг. И рок его, и казнь его тоже была - думать. Ещё два десятилетия, подобно арестанту $c$ двадцатилетним сроком, он должен был жить» (Солженицин 90). Тут виділяємо експресивний уривок, де атрибути думання у свідомості вождя позначено іменниками долг, рок, казнь. Як парадокс визначаємо порівняння володаря країни 3 арештантом («подобно арестанту $c$ двадцатилетним сроком»), до того ж таким Сталін зробив себе сам.

Вище було проаналізовано парадоксальні ситуації, що обмежені свідомістю однієї особи, а тому не мають безпосереднього впливу на інших осіб або більший простір. Натомість $є$ й інші - що не лише суперечать здоровому глузду, а й небезпечні. Порівняймо: «Прав был Ленин, и в виде исключения также и Троцкий прав: если без суда не расстреливать - 
вообще ничего невозможно сделать в истории» (Солженицин 101). Виділена теза - афоризм, що характеризує тирана, а тому введений автором у конструкцію його НПМ - для більшої суб’єктивації оповіді. Але це суперечить канонам усіх гуманістичних релігій світу та законів людського співіснування з акцентом на атрибуті «без суда» і тому $\epsilon$ парадоксом у соціальному вимірі.

Ще більший простір парадоксальності стосується цілих народів. Порівняймо:

Изменили украинцы (была такая мечта в 44-м: выселить всю Украину в Сибирь, да некем заменить, много слишком); изменили литовцы, эстонцы, татары, казаки, калмыки, чечены, ингуши, латыши - даже опора революции латыши! И даже родные грузины, обережённые от мобилизаций, - и те как бы не ждали Гитлера! (Солженицин 107).

У виділених ознаках Сталін-оповідач у межах внутрішнього мовлення акцентує на сутності тієї зради: «как бы не ждали Гитлера», тобто їхній злочин полягає лише в перебуванні на окупованій території. Після того ще довго (до кінця 60-х років) в анкетах потрібно було зазначати про таке перебування родичів. Виділена в дужках інформація (реальна, існує така інструкція) - також від наратора, суб'єктивними показниками мовлення якого є слово мечта та імпульсивність у фразі «да некем заменить, много слишком».

Парадоксальність тут полягає в кількох смислових площинах: це ступінь провини цілих народів і численний перелік цих «винних» народів, серед яких мовець найбільш емоційно акцентує на трьох («выселить всю Украину в Сибирь», «даже опора революции латыши!», «даже родные грузины»). Можна навести аналогію з 20-ми роками, коли політику коренізації було введено лише в Україні та Грузї̈, а метою ї̈ сучасні дослідники зазначають виявлення «націоналістичного елементу». Це пояснює таку прискіпливу увагу диктатора до цих народів.

Отже, парадокс примушує читача активізувати своє мислення, що робить експресивним сприйняття й подальшого тексту. Традиційно поряд із парадоксальними й антитезовими елементами експресію в художньому тексті створюють метафори, метонімії, епітети, повтори та інші засоби. Так, у реченні «А по остальным часам, как по острым камням, надо было ползти, перетягиваться уже не молодым, уязвимым телом» (Солженицин 90) виділена метафора позначає відчуття вже зазначеного вище потерпання літньої людини від політики Сталіна, до того ж конструкція по часам у ролі обставини набуває просторового характеру саме в семантичній площині акціональних дієслів ползти, перетягиваться, а також об'єктивована порівнянням «как по острым камням».

Порівняймо ще: «Всякий неподозрительный человек, подойдя со стороны, увидел бы тут застывший ураган исследовательской мысли» (Солженицин 25). У цьому реченні виділена метафора $є$ більш стертою - аж до фразеологічного статусу. Імпровізація автора-наратора виявляється 
лише в характеризуванні дослідницької думки за допомогою епітета застывший. Але за сюжетом це ознака не припинення процесу, а застиглої картинки - кадру.

Порівняймо ще: «Не только стальной не была его воля тогда, но раздвоилась совсем, он потерял себя $u$ не видел выхода» (Солженицин 95). У реченні позначені дві метафори - перша авторська, друга - стерта. Але авторська метафора виявляє опосередковану стертість через використання стертого епітета стальная (воля).

У тексті трапляються й метонімії. Наприклад, у реченні «Прянчиков даже не догадался, что это - кабинет (так он был просторен) и что пара золотых погонов в конце зала есть хозяин кабинета» (Солженицин 80) у виділеній конструкції словосполучення «пара золотых погонов» позначає міністра (за головним візуальним атрибутом), що конкретизовано другою частиною фрази в межах НПМ персонажа. В іншому випадку ситуація 3 аналізом метонімії складніша: «Так даже национальный вопрос посмеялся над ним в те тяжёлые годы...» (Солженицин 107). Тут у виділеній конструкції відзначаємо тогочасний ідеологічний термін нащиональный вопрос, що має абстрактну природу й широку семантичну сферу, але в такому контексті він опредметнений i метафорично уособлений.

Слід зазначити, що деякі метафори не сприймаються вже такими, оскільки це може вже відповідати певним фізичним процесуальним ознакам. Наприклад, у фрагменті «Пила брызнула коричневым порошком коры. Пила шла не так ловко, как со Спиридоном, но всё же легко. Друзья за многие утра спилились, и дело у них обходилось без взаимных упрёков» (Солженицин 150) виділені словосполучення на позначення столярної операції вже здебільшого належать до професійного жаргону (можливо, у першому дієслово брызнула має деякий метафоричний відтінок в умовах семантичної переваги фізичної ознаки дії). Також відзначаємо авторський неологізм спилились, що має семантику спільної звичної дії, однак за аналогією сприймається як оказіоналізм спились, що також має сему спільності.

Як елементи загальної текстової експресії відзначаємо також контрастне протиставлення. Наприклад, у фрагменті «У него было особенно хорошее расположение духа от прихода в просторную светлую комнату из тёмной подвальной аккумуляторной с плохой вентиляцией, где он по четырнадцать часов в день копался кротом» (Солженицин 316) виділені синтаксичні конструкції протиставлено за якісною ознакою светлая темная та більш відносно просторная - подвальная аккумуляторная (апріорі невелике приміщення, характеризоване ще й негативно конотованим неузгодженим означенням с плохой вентиляцией). Відзначаємо тут також метафоричну ознаку виконуваної там роботи, виражену словосполученням копался кротом із синтаксичною функцією способу дії, що семантично й репрезентує означені вище умови. 
Ще один відомий прийом - повторення - акцентує на певному об'єкті чи дії. Наприклад, у діалогічних фрагментах «-Просим, Лёва! Просим!» (Солженицин 319) та «-Суд! Суд! - требовали голоса» (Солженицин 321) виділені повторювані слова створюють емфазу - підкреслюють не лише одностайність аудиторії, але й надають динаміки ситуації. Аналогічний ефект у тексті створюють послідовності однорідних дієслів і обставин. Порівняймо: "с неистощимым терпением он молчал, мямлил, тянул, уклонялся, ёрзал на стуле - и так-таки не подписал обязательства» (Солженицин 316-317) (протиставлення виділених дієслів недоконаного виду і дієслова доконаного виду із семантикою підсумку) та «Как всегда, под подушкой у него, под матрасом, под кроватью и в тумбочке вперемежку с едой лежало десятка полтора переданных ему в передачах самых интересных (для него одного, потому их и не растаскивали) книг» (Солженицин 318) (виділені обставини виконують не лише формальну роль вказівки на місце, а й створюють експресію наративу).

Функцію акцентування на певних характеристиках виконує й такий зовнішній показник, як послідовність слів із великої літери. Так, у фрагменті «он написал письмо на имя Председателя Совета Министров товарища Сталина о том, что, если ему, Исааку Кагану, Правительство предоставит возможность, он берётся осуществить управление по радио торпедными катерами» (Солженицин 317) через виділені статусні назви та прізвища оповідач Каган створює атмосферу пафосу для самоствердження й підняття таким способом власного статусу.

Семантично експресивність передовсім пов'язана 3 вираженням емоцій окремого персонажа, які передано в його внутрішніх монологах або зовнішніх діалогах. Наприклад:

- Довольно! - с ожесточением вырывался Прянчиков. - Мне надоели прокуроры! Мне надоели ваши суды! Какое право имеет один человек судить другого? Ха-ха! Смешно! Я презираю вас, парниша!- крикнул он председателю суда. - Я ... вас! (Солженицин 321).

У цій репліці передано імпульсивний характер мовлення Прянчикова, його емоції: кожне речення коротке і має окличну інтонацію (навіть виділене - формально питальне). Показниками емоційності $\epsilon$ й вигуки та нецензурна фраза, маркована трьома крапками, а також авторська характеристика такого мовлення через дієслівне словосполучення «с ожесточением вырывался», яке семантично передає таку імпульсивність і через характеристичний іменник, і через акціональне дієслово.

Висновки та перспективи дослідження. Відповідно до визначення головної функції експресивних рис у художньому тексті як таких, що характеризують оповідь загалом і мовлення героїв зокрема, виявлено експресивно-стилістичні елементи, що додають описові динаміки, а також посилюють, виділяють, підкреслюють емоційне чи естетичне наповнення тексту. Серед таких стилістичних прийомів і засобів визначено й проаналізовано в тексті роману Олександра Солженіцина «У колі 
першому» вживання розмовної (просторічної, діалектної тощо) лексики, повторів (зокрема емфази), недомовок, метафоричних конструкцій, іронічних і парадоксальних (антитезових) контентів, контрасту, у межах синтаксичної організації - окличних і питальних конструкцій, мовленнєвих ознак імпульсивності. Перспективним бачимо подальше грунтовне дослідження стилістики роману Олександра Солженіцина «У колі першому».

\section{Список використаної літератури}

Бахтин, Михаил. Автор и герой: К философским основам гуманитарных наук. СанктПетербург: Азбука, 2000.

Великий тлумачний словник сучасної української мови, за ред. В. Т. Бусла. Київ; Ірпінь: ВТФ «Перун», 2001.

Виноградов, Виктор. Избранные труды. Язык и стиль русских писателей. От Гоголя до Ахматовой. Москва: Наука, 2003.

Вольф, Елена. «Эмоциональные состояния и их представления в языке». Логический анализ языка. Проблемы интенсиональных и прагматических контекстов. Москва, 1989, с. 55-75.

Гулак, Анатолий. Стилистический анализ художественного текста. Харьков: Издательство Иванченко И. С., 2019.

Гулак, А., и Меняйло, Н. «О стилистической культуре повествования в романе А. И. Солженицина “В круге первом"». Русская филология. Вестник Харьковского национального педагогического университета имени Г. С. Сковороды, т. 1, № 63, 2018, c. 9-14. doi.org/10.5281/zenodo.1243650

Клеофастова, Тетяна. «Червоне колесо» О. I. Солженіцина в контексті розвитку російської літератури ХХ століття. Автореф. дис. ... д-ра филол. наук: 10.01.02. Київ, 2002.

Ковтунова, И. «Проблема несобственно прямой речи в трудах В. В. Виноградова». Вопросы языкознания, № 1, 2002, с. 65-71.

Меняйло, Н. В. «Стилистико-речевое построение образа Спиридона Егорова в романе А. И. Солженицына “В круге первом"». Русская филология. Вестник Харьковского национального педагогического университета имени Г. С. Сковороды, т. 1, № 67, 2019 , с. $57-63$.

Падучева, Елена. Семантические исследования: Семантика времени и вида в русском языке; Семантика нарратива. 2-е узд. Москва: Языки славянской культуры, 2010.

Солженицин, Александр. В круге первом: роман. Москва: Наука, 2006.

Филатова, Елена. «Интонация как способ делимитации и подачи исходных речевых единиц при порождении речи и опора при адекватном её восприятии». Русский язык, литература, культура в школе и вузе, № 5, 2013, с. 17-23.

Шкурська, Оксана. Синтаксис прози Валентина Распутіна (комунікативноструктурний аспект). Атореф. дис. ... канд. филол. наук: 10.02.02. Харків, 2007.

Штайн, Клара. Поэтический текст в научном контексте. Санкт-Петербург-Ставрополь, 1996.

Шульгина, Валентина. Структурно-семантические типы эллиптических конструкций в русской разговорной речи. Автореф. дис. ... канд. филол. наук: 10.02.01. Киев, 1990. 


\section{References}

Bahtin, Mihail. Avtor i geroj: K filosofskim osnovam gumanitarnyh nauk. Sankt-Peterburg: Azbuka, 2000.

Velykyi tlumachnyi slovnyk suchasnoi ukrainskoi movy, edited by V. T. Busel. Kyiv; Irpin: VTF "Perun", 2001.

Vinogradov, Viktor. Izbrannye trudy. Jazyk i stil' russkih pisatelej. Ot Gogolja do Ahmatovoj. Moskva: Nauka, 2003.

Vol'f, Elena. «Jemocional'nye sostojanija i ih predstavlenija v jazyke». Logicheskij analiz jazyka. Problemy intensional'nyh i pragmaticheskih kontekstov. Moskva, 1989, pp. 55-75.

Gulak, Anatolij. Stilisticheskij analiz hudozhestvennogo teksta. Har'kov: Izdatel'stvo Ivanchenko I. S., 2019.

Gulak, A. and Minyailo, N. "The stylistic structure of narration in the novel "In the First Circle"” by A. I. Solzhenitsyn. Russkâ̂ filologiâ, vol. 1, no.63, 2018, pp. 9-14. doi.org/10.5281/zenodo.1243650

Kleofastova, Tetiana. "The Red Wheel" by A. I. Solzhenitsin in the context of the XXth century Russian literature development. Doctoral Thesis Abstract. Kyiv, 2002.

Kovtunova, I. "Problema nesobstvenno prjamoj rechi v trudah V. V. Vinogradova". Voprosy Jazykoznanija (Topics in the Study of Language). no. 1, 2002, pp. 65-71.

Minyailo, N. "The stylistic and speech construction of the image of spiridon egorov in the novel by A. I. Solzhenitsyn "In the First Circle"”. Russkâ̂ filologiâ, vol. 1, no. 67, 2019, pp. 57-63.

Paducheva, Elena. Semanticheskie issledovanija: Semantika vremeni i vida v russkom jazyke; Semantika narrativa. $2^{\text {nd }}$ ed. Moskva: Jazyki slavjanskoj kul'tury, 2010.

Solzhenicin, Aleksandr. In the First Circle. Moskva: Nauka, 2006.

Filatova, Elena. "Intonacija kak sposob delimitacii i podachi ishodnyh rechevyh edinic pri porozhdenii rechi i opora pri adekvatnom ejo vosprijatii". Russkij jazyk, literatura, kul'tura v shkole i vuze, no. 5, 2013, pp. 17-23.

Shkurska, Oksana. Syntax of the Prose by V. Rasputin (communicative-structural aspect). PhD Thesis Abstract. Kharkiv, 2007.

Shtajn, Klara. Pojeticheskij tekst v nauchnom kontekste. Sankt-Peterburg-Stavropol', 1996.

Shul'gina, Valentina. Strukturno-semanticheskie tipy jellipticheskih konstrukcij $v$ russkoj razgovornoj rechi. PhD Thesis Abstract. Kiev, 1990. 